\title{
ODPOWIEDZIALNOŚĆ III RP ZA SZKODY WYRZĄDZONE PRZEZ WŁADZE PUBLICZNE W LATACH 1944-1989*
}

Omawiany temat wpisuje się w problematykę ,solidarności międzypokoleniowej". Chodzi w nim bowiem nie tylko o szkody wyrządzone z powodów ustrojowo-politycznych żyjącym jeszcze obywatelom przez władze publiczne w latach 1946-1989, lecz także o obciążenie kosztami odpowiedzialności za te szkody nowych pokoleń, które z tamtymi wydarzeniami nie miały nic wspólnego.

U podstaw rozważań nad powyższymi sprawami leżą dwa założenia: 1) za szkodę odpowiada jej sprawca lub następca prawny oraz 2) naprawa jednych szkód nie powinna powodować powstawania innych.

Pierwsze założenie wymaga zastanowienia się nad odpowiedzialnościa struktur państwowych funkcjonujących po 1939 r. na obszarze Polski $\mathrm{w}$ dawnych granicach $\mathrm{z}$ okresu XX-lecia międzywojennego oraz $\mathrm{w}$ granicach dzisiejszych. Dopiero na tym tle można poszukiwać odpowiedzi na pytanie, czy III Rzeczpospolita Polska zobowiązana jest do naprawiania szkód wyrządzonych przez ówczesne struktury państwowe ${ }^{1}$.

Nie budzi na ogół wątpliwości odpowiedzialność III Rzeszy Niemieckiej za szkody wyrządzone przez nią na okupowanych ziemiach Polski. Sporne moga być jedynie formy i wysokości odszkodowań. Natomiast sprawca jest oczywisty, jest nim III Rzesza, tak jak oczywista jest odpowiedzialność jego następczyni prawnej, to jest Republiki Federalnej Niemiec. Nie ma dlatego podstaw prawnych, aby domagać się zadośćuczynienia od innych podmiotów, a zwłaszcza od Państwa Polskiego. Innym zagadnieniem są pojawiające się niekiedy żądania kierowane do władz polskich o odszkodowania za szkody poniesione w związku z przesiedleniem obcych obywateli z obecnych terytoriów Polski (problem tzw. wypędzonych). Z punktu widzenia przytoczonego wyżej pierwszego założenia, także ta sprawa nie nastręcza poważniejszych trudności. Sprawcami owych przesiedleń i szkód z tym związanych były ,,wielkie mocarstwa", które - bez udziału Polski - zadecydowały o jej powojennych granicach i o potrzebie odpowiedniego przemieszczenia ludności. Nie ma więc wystarczających podstaw prawnych do domagania się od Polski odszkodowań z tytułu tych wydarzeń. Nie dotyczy to poszczególnych, jednostkowych

\footnotetext{
* Artykuł prezentuje własne poglądy autora i abstrahuje od dotychczasowej praktyki oraz obowiązujących regulacji prawnych odnoszących się do spraw związanych z tytułem.

1 Pojęcie „III Rzeczpospolita Polska” jest określeniem występującym w języku prawnym, także w Konstytucji RP.
} 
przypadków późniejszych przesiedleń (najczęściej byłych obywateli polskich). W takich sprawach potrzebny jest wyrok sądu badającego wszystkie indywidualne uwarunkowania prawne, w tym zwłaszcza nieuporządkowane księgi wieczyste. Nie są to jednak przypadki odnoszące się do masowych przesiedleń związanych ze zmianą granic.

Podobna sytuacja występuje na dawnych wschodnich terenach Polski, które decyzją obcego mocarstwa zostały przyłączone do ZSRR. Nastąpiło to także bez udziału prawowitych władz Polski. Nie powinno więc budzić wątpliwości to, że za wszelkie szkody $\mathrm{z}$ tym związane odpowiada ich sprawca, a zarazem beneficjent, to jest ZSRR, którego prawnym sukcesorem jest obecnie Federacja Rosyjska. Sprawę komplikuje jednak to, że w omawianym zakresie beneficjentami - po upływie kilkudziesięciu lat - stały się także niepodległe nowe państwa: Litwa, Białoruś i Ukraina, których dzisiaj nie można obciążać winą za krzywdy wyrządzone przez inne państwo.

Pomimo tych komplikacji uprawnione jest twierdzenie, że za krzywdy wyrządzone na tamtych terenach przez władze ZSRR nie ponosi odpowiedzialności III Rzeczpospolita. Chodzi tu nie tylko o odszkodowania za straty materialne (zwłaszcza jeżeli nie da się ich zrekompensować mieniem uzyskanym na terytoriach zachodniej Polski), ale także o cierpienia związane z utratą życia i wolności milionów obywateli, o prześladowania na tle narodowościowym, o upokorzenia oraz wiele innych cierpień zadawanych ludności polskiej. Za te wszystkie nieszczęścia powinien odpowiadać ich sprawca, to znaczy dawniej ZSRR, a obecnie Federacja Rosyjska. Problem polega jednak na tym, że - abstrahując od kwestii ewentualnego przedawnienia niektórych roszczeń - ów sprawca jest militarnym mocarstwem świadomym tego, iż może bezkarnie lekceważyć reguły cywilizowanego prawa i nie reagować na roszczenia swoich ofiar.

W tej sytuacji dopuszczalna, a nawet konieczna staje się pomoc dla tych ofiar ze strony władz III Rzeczypospolitej. Jednak pomoc ta powinna być udzielana nie na podstawie prawa do odszkodowania, lecz w oparciu o przesłanki etyczne, wynikające $\mathrm{z}$ potrzeby troski Państwa o własnych obywateli. Dotyczy to w szczególności osób, które żyją w niedostatku, a ich cierpienia związane sa z sytuacjami, o których mowa wyżej. Wysokość tej pomocy nie może być dlatego określana według reguł obowiązujących na przykład w postępowaniu sądowym, lecz powinna być udzielana $\mathrm{z}$ motywów moralnych i przy uwzględnieniu możliwości finansowych Państwa.

Inaczej trzeba rozpatrywać sprawę odpowiedzialności za szkody wyrządzone przed 1989 r. przez władze publiczne na obszarze Polski w jej obecnych granicach. Od 1944 r. na tym terytorium (początkowo tylko na jego części) funkcjonowały struktury państwowe, które nominalnie nawiązywały do państwowości polskiej. Może to sugerować, że niezależnie od charakteru ustrojowego, było to suwerenne Państwo Polskie, którego następcą prawnym stała się obecnie III Rzeczpospolita Polska. To pozornie poprawne rozumowanie ma jednak istotna wadę. Zakłada bowiem, że po II wojnie światowej istnieje ciaggłość prawna Państwa Polskiego, różniącego się jedynie charakterem ustroju. Natomiast w rozumowaniu tym pomija się sprawę suwerenności, która dla omawianej problematyki ma znaczenie podstawowe. O ciągłości prawnej 
można bowiem mówić tylko wówczas, gdy dane państwo zachowywało suwerenność niezależnie od zmian ustrojowych. Dlatego następcą prawnym III Rzeszy Niemieckiej jest Republika Federalna Niemiec, a Federacja Rosyjska jest sukcesorem ZSRR. W obydwu przypadkach chodzi bowiem zawsze o państwa suwerenne. Powstaje pytanie, czy analogiczne twierdzenie można odnieść do relacji pomiędzy PRL a III Rzeczapospolitą Polska.

Dobrym punktem wyjścia odpowiedzi na powyższe pytanie może być niezwykle ważna, ale nieco zapomniana - lub celowo pomijana - uchwała Senatu RP dotycząca tej kwestii ${ }^{2}$. Senat stwierdza w tej uchwale, że państwo utworzone w wyniku II wojny światowej na ziemiach polskich i funkcjonujące w latach 1944-1989 było nie tylko niedemokratyczne, o totalitarnym systemie władzy, ale będąc elementem światowego systemu komunistycznego, pozbawione było suwerenności i nie realizowało zasady zwierzchnictwa Narodu ${ }^{3}$. W związku z tym ,,[...] Senat uznaje ciagłość prawną II i III Rzeczypospolitej wyrażająca się $\mathrm{w}$ ich suwerennym i niepodległym bycie [...]" ${ }^{4}$. Tym samym Senat RP nie uznał ciaggłości prawnej między PRL a III Rzecząpospolita.

Konsekwencją takiego stanowiska Senatu jest stwierdzenie, że ,,[...] akty normatywne stanowione przez niesuwerennego prawodawce $\mathrm{w}$ latach 1944-1989 pozbawione są mocy prawnej, jeśli godziły w suwerenny byt państwa polskiego lub sa sprzeczne $\mathrm{z}$ zasadami prawa uznawanymi przez narody cywilizowane, znajdującymi swój wyraz w Powszechnej Deklaracji Praw Człowieka. Dotyczy to w szczególności aktów normatywnych naruszających podstawowe prawa i wolności obywatelskie. Zaliczyć do nich należy akty pozbawiające obywatelstwa polskiego, czyniące $\mathrm{z}$ prawa karnego narzędzie prześladowania ludzi walczących o niepodległość lub różniących się przekonaniami światopoglądowymi, a także akty, na których podstawie dokonano niesprawiedliwego pozbawienia własności [...]" ${ }^{5}$. W świetle art. 87 Konstytucji RP omawiana tu Uchwała Senatu RP nie jest aktem prawa powszechnie obowiązującego. Dlatego formalne stwierdzenie nieważności wspomnianych aktów normatywnych rangi ustawowej wymagałoby potwierdzenia ustawowego albo - w odniesieniu do innych aktów normatywnych decyzji właściwych organów władzy państwowej ${ }^{6}$. Wprawdzie dotychczas takie formalne potwierdzenie nieważności w sposób generalny nie nastąpiło (zdarzało się to jedynie $\mathrm{w}$ przypadkach indywidualnych), ale istota problemu nadal istnieje.

Skoro władze państwowe, w tym władze prawodawcze, istniejące na terytorium dzisiejszej Polski w latach 1944-1989 nie były władzami suwerennego Państwa Polskiego, to ustanawiane wówczas akty normatywne nie powinny mieć obecnie mocy prawnej, jeżeli nie zostały uznane przez to suwerenne Państwo. Dobrych przykładów rozwiązania podobnych problemów dostarcza sytuacja Polski po odzyskaniu niepodległości po I wojnie światowej. Bardzo

\footnotetext{
${ }^{2}$ Uchwała Senatu Rzeczypospolitej Polskiej z 16 kwietnia 1998 r. o ciągłości prawnej między II a III Rzecząpospolitą Polską (dalej jako: Uchwała Senatu RP z 16 kwietnia 1998 r.).

${ }^{3}$ Por. ibidem, art. 1.

${ }^{4}$ Ibidem, art. 2.

${ }^{5}$ Ibidem, art. 4.

${ }^{6}$ Por. ibidem.
} 
sprawnie rozwiązano sprawę obowiązywania prawa pochodzącego od władz państw zaborczych ${ }^{7}$. Inne, obowiązujące obecnie regulacje prawne sa nieracjonalne, mało logiczne i stwarzaja wiele nierozwiązywalnych trudności prawnych. Co więcej - prowadzą do sytuacji niesprawiedliwych, czego wyrazem jest między innymi obciażanie obywateli suwerennego państwa odpowiedzialnością za działania będące realizacją decyzji obcego imperium. Ponadto paradoksem jest to, że warunkiem przyznania odszkodowania najczęściej jest fakt naruszenia obowiązującego wówczas prawa. A przecież celem tego prawa było właśnie wyrządzanie krzywd, których naprawienie jest przedmiotem dzisiejszych postępowań w wielu sprawach majątkowych i karnych.

Omówiona wyżej uchwała Senatu RP nie ma wyłącznie politycznego znaczenia. Nie jest tylko stanowiskiem jednych ugrupowań politycznych, które odniosły zwycięstwo nad inną siłą polityczną. Jej uzasadnienie wynika z realiów historycznych i z prawdy o uwarunkowaniach ustrojowych powojennego półwiecza. Należy tu uwzględnić co najmniej cztery czynniki związane z następującymi pytaniami dotyczącymi tamtego okresu: 1) kto decydował o ustroju państwa, 2) gdzie był ośrodek decyzyjny w sprawach polityki zagranicznej, 3) kto sprawował nadzór nad tak zwanymi strukturami siłowymi (wojsko, organy bezpieczeństwa wewnętrznego) oraz 4) kto miał faktyczny wpływ na obsadę najważniejszych stanowisk publicznych. We wszystkich czterech kwestiach odpowiedź jest taka sama. W wymienionych sprawach rzeczywiste decyzje zapadały zgodnie $\mathrm{z}$ wola kierowniczych sił ZSRR. Faktu tego nie zmieniały pozory samodzielnych działań przez władze poszczególnych państw satelickich, do których wtłoczona została także Polska. Stwierdzeniu temu nie przeczy fakt, że całego powojennego okresu, aż do 1989 r., nie można traktować jako okupacji militarnej, a także że opresyjność polityczna przybierała różne formy i natężenie: od jawnego terroru, poprzez represje tak zwanego okresu stalinowskiego, złagodzenie tego stanu po 1956 r., kolejne okresowe zwiększanie represyjności w latach siedemdziesiątych i znowu drastyczne zaostrzenie terroru w latach 80. Na twierdzenie o braku suwerenności w podstawowych sprawach nie wpływa także epizodyczne zwiększanie zakresu kompetencji tamtego Państwa. Po pierwsze, dlatego że zakres ten dotyczył spraw drugorzędnych, nieobejmujących żadnej z wymienionych wyżej czterech dziedzin. Po drugie, margines swobody zależał od woli sił zewnętrznych i wbrew tej woli nie mógł być dowolnie zwiększany. Twierdza tak nawet osoby sprawujące $\mathrm{w}$ tamtym czasie najważniejsze funkcje publiczne - między innymi sprawcy stanu wojennego w $1981 \mathrm{r}$. Wreszcie po trzecie, przyznanie pewnego marginesu niezależności w sprawach drugorzędnych pozorowało istnienie odrębnego bytu państwowego, co było potrzebne do uznania międzynarodowego oraz pozyskania przychylności niewyrobionych politycznie obywateli ${ }^{8}$.

Przedstawione wyżej uwagi dotyczące braku rzeczywistej suwerenności państwa funkcjonującego na obszarze Polski w okresie od II wojny światowej do 1989 r. pozwalają zakwestionować automatyzm odpowiedzialności III RP za szkody wyrządzone przez władze tamtego państwa.

\footnotetext{
${ }^{7}$ Por. np. art. 126 tzw. Konstytucji marcowej z 1921 r.

${ }^{8}$ Por. W. Łączkowski, Ekspertyza prawna dotyczaca projektu uchwaty Senatu RP stwierdzajacej ciagtość prawna między III a II Rzeczapospolita Polska (niepublikowana).
} 
W tej sytuacji powstaje problem uczciwego rozwiązania owego dylematu. Możliwe są tu dwa wyjścia. Po pierwsze - uwzględniając założenie, że za szkodę odpowiada jej sprawca - należałoby pomoc dla poszkodowanych oprzeć na przesłankach etycznych wynikających $\mathrm{z}$ solidaryzmu społecznego i przy uwzględnieniu stanu finansów publicznych. Byłyby to w zasadzie takie same reguły, jakie postulowano wobec poszkodowanych na dawnych polskich kresach wschodnich. Różnica dotyczy jedynie mienia, które stanowi do dzisiaj przedmiot bezpodstawnego wzbogacenia obecnych władz publicznych lub innych podmiotów, które odniosły z tego tytułu korzyści w złej wierze. W tym zakresie można by posługiwać się rozwiązaniami prawnymi podobnymi do tych, które przewiduje Kodeks cywilny ${ }^{9}$.

W rozważaniach nad problemem odszkodowań za szkody wyrządzone przez władze publiczne w latach 1946-1989 należy mieć na uwadze także drugie założenia, o którym była mowa na wstępie, to jest zasadę, że naprawa jednych krzywd nie powinna wyrządzać innych szkód. Dotyczy to na przykład skutków tak zwanej reformy rolnej z 1944 r. Jej istotą było nie tylko odebranie majątków ziemianom, ale także wyeliminowanie ich z życia społecznego poprzez różne szykany, zakaz osiedlania się na określonych terenach i tym podobne. Poza tym - wbrew pozorom - dalekosiężnym celem tej reformy nie było trwałe pozostawienie małorolnym chłopom ziemi przekazanej im $\mathrm{w}$ ramach parcelacji majątków ziemskich. Celem tym była bowiem w dalszej perspektywie kolektywizacja wsi, która wprawdzie w Polsce nie do końca się udała, ale stanowiła dalekosiężny program ustroju komunistycznego. Niemniej jednak - mimo obłudnej przewrotności i niesprawiedliwości dekretu o reformie rolnej - upływ czasu spowodował, że skutki reformy ze względów moralnych sa dzisiaj nieodwracalne. Naprawianie krzywd wyrządzonych właścicielom ziemskim blisko 70 lat temu nie powinno polegać na powodowaniu nowych krzywd rolnikom i ich spadkobiercom, którzy w dobrej wierze gospodarują od dziesięcioleci na ziemiach zabranych prawowitym właścicielom.

Do powyższych spraw nawiązuje cytowana wyżej uchwała Senatu RP z 1998 r., która w ostatnim zdaniu stwierdza między innymi: „,[...] Zapewnić równocześnie należy [...] ochronę praw nabytych, na podstawie uznanych za nieważne aktów normatywnych, chyba że nabycie było niegodziwe" ${ }^{10}$. Oznacza to, że gdyby nawet doszło w przyszłości do formalnego unieważnienia dekretu o reformie rolnej, rolnikom, którzy otrzymali na jego podstawie ziemię, w zasadzie nie groziłaby jej utrata.

Wreszcie na zakończenie należy wskazać na dwa zastrzeżenia. Po pierwszewszystkie przedstawione wyżej wnioski, zwłaszcza odnoszące się do sprawy suwerenności, dotyczą wyłącznie problematyki prawa wewnętrznego, bez konotacji z uwarunkowaniami międzynarodowymi. Próby kwestionowania obecnie zdarzeń międzynarodowych, których uczestnikiem lub najczęściej tylko przedmiotem była w omawianym okresie atrapa Państwa Polskiego, byłyby mało realne, a nawet szkodliwe. Na przykład nie można dzisiaj kwestionować granic, które wprawdzie wytyczone zostały bez udziału Polski,

\footnotetext{
${ }^{9}$ Kodeks cywilny, ks. III, tyt. V, art. 405 i n.

${ }^{10}$ Uchwała Senatu RP z 16 kwietnia 1998 r., art. 4.
} 
ale są powszechnie uznawane przez społeczność międzynarodową i dotyczą nie tylko Polski. Podobnie podważanie wszystkich zobowiązań międzynarodowych podjętych przez ówczesny twór państwowy mogłoby przynieść więcej szkód, aniżeli korzyści, nie wspominając nawet o nikłym prawdopodobieństwie realizacji podnoszonych $\mathrm{w}$ tym zakresie postulatów.

Po drugie - powyższe rozważania tylko $\mathrm{w}$ bardzo ograniczonym zakresie dotyczyć moga Kościoła katolickiego w Polsce, a także innych Kościołów i związków wyznaniowych. W szczególności w dyskusji o odszkodowaniach na rzecz Kościoła należy uwzględnić także problematykę jego bieżącego finansowania. W państwach demokratycznych Kościoły są traktowane inaczej aniżeli firmy komercyjne, czy indywidualni obywatele. Na ogół uznawane jest bowiem ich znaczenie w życiu wielu osób. Dotyczy to nie tylko trudno wymierzalnych spraw duchowych, lecz często także bardzo konkretnych i wymiernych zadań publicznych na przykład w dziedzinie oświaty, opieki medycznej, ochrony zabytków i dziedzictwa narodowego, działań charytatywnych. Spełniając te zadania, Kościoły odciążają w tym zakresie władze publiczne. Dlatego istnienie zasobów majątkowych oraz finansowanie Kościołów ze środków publicznych na ogół nie jest kwestionowane i w demokracjach europejskich jest standardem. Różnice dotyczą jedynie form i wysokości tego finansowania. Informacje na ten temat są łatwo dostępne, chociaż mało znane. Jest to powód, dla którego tematyka odszkodowań kościelnych powinna być elementem szerszego problemu finansowania Kościołów, a to wymaga odrębnego opracowania.

prof. dr hab. Wojciech Eaczkowski

Uniwersytet im. Adama Mickiewicza w Poznaniu

\title{
LIABILITY OF THE THIRD REPUBLIC OF POLAND FOR THE DAMAGE CAUSED IN THE PERIOD 1944-1989
}

\author{
Summary
}

\begin{abstract}
Pursuant to the principle that the perpetrator or his legal successor is liable for the damage caused, The Third Republic of Poland shall not be held liable for the damage resulting from the actions taken by public authorities that functioned in the territory of Poland in the political regime of 1944-1989. Those authorities, in all fundamental matters, did not act independently, but merely implemented the decisions, also the damaging ones, that had been made by the Soviet Union. And yet, it is highly unlikely that the Russian Federation (the legal successor of the USSR) will ever recognise any claims for damages or compensation for the damage caused. Consequently, other possibilities must be considered. What seems possible and recommended is assistance offered to the harmed citizens, although such assistance is not provided by the law but is rooted in the principles of ethic and depends on the financial capability of the State involved. Solutions similar to those provided in the Civil Code should be resorted to only in situations where the state of unjust enrichment continues to be enjoyed by today's public authorities, or individuals who acquired unlawful gains in bad faith, at the cost of others.

The deliberations presented in the paper apply to the internal situation in the state only since the fact that in the analysed period Poland was not a sovereign state will not, any longer, have any practical consequences for international relations. Further, the subject matter of this paper does not concern compensation due to the Church and religious denominations, which is part of a much more broadly understood area pertaining to the financing of Churches.
\end{abstract}

